\title{
Alternative tools to mass production and human performance indicators in sheltered work centers of Valencian community (Spain)
}

\author{
Juan A. Marin-Garcia ${ }^{1}$, Cristobal Miralles ${ }^{1}$, Julio J. Garcia-Sabater ${ }^{1}$, M. Rosario Perello- \\ Marin $^{2}$ \\ ${ }^{1}$ ROGLE - Departamento de Organización de Empresas. Universidad Politécnica de Valencia. \\ (SPAIN) \\ ${ }^{2}$ Departamento de Organización de Empresas. Universidad Politécnica de Valencia. (SPAIN) \\ jamarin@omp.upv.es; cmiralles@omp.upv.es;jugarsa@,omp.upv.es; rperell@upvnet.upv.es
}

Received June 2010

Accepted September 2011

\section{Abstract:}

Purpose: The most popular alternative systems to mass production at an academic level (lean manufacturing, agile manufacturing, flexible customization, mass customization...) share many characteristics. Our article identifies an extensive set of alternative practices to mass production; analyzes the classification of practices in categories (Flow, TQM, TPM, Customer Relations, Supplier Relations and Human Resources Practices) and analyzes the impact on several human performance indicators such as satisfaction, absenteeism, voluntary turnover, permanent contracts, knowledge, personal \& social adjustment activities and integration of workers into ordinary companies.

Design/methodology/approach: Survey in sheltered work centers. We use regression analysis in order to prove relations between explicative and criterion variables.

Findings: The results of our research allow us to identify that human resource management and customer relationship practices have significant effects on job 
satisfaction, knowledge, integration into ordinary companies and personal and social adjustment.

Research limitations/implications: Data came only from one industry; therefore the results would not be directly generalized to other contexts.

Practical implications: Managers in Sheltered work centers can estimate the impact of the deployment of alternative tools to mass production.

Originality/value: There are few papers relating lean manufacturing tools and human resources performance indicators. At the same time, there are very few research carried out in sheltered work centers context.

Keywords: lean production, high involvement work practices, sheltered work centers

\section{Introduction}

The number of scientific publications related to mass production alternative systems in the last 20 years is abundant. The most popular alternative system proposal in the academic world is lean manufacturing, although other ways to refer to the production systems that share many characteristics with lean manufacturing cannot be left aside. For example, agile manufacturing (Agarwal, Shankar \& Tiwari, 2006; Vazquez-Bustelo \& Avella, 2006a), flexible customization (Narain, Yadav \& Antony, 2004; Agarwal et al., 2006), mass customization (Ismail, Reid, Mooney, Poolton \& Arokiam, 2007; Brown \& Bessant, 2003).

Our research is enclosed within the line different authors are working at international level (Holweg, 2007; Shah \& Ward, 2007; Portioli Staudacher \& Tantardini, 2007) and cast up from the recent adaptations to create and to validate questionnaires of operation management practices in Spanish (Martín Peña \& Díaz Garrido, 2007; Tari, Molina \& Castejón, 2007; Urgal González, Diz Comesaña \& García Vázquez, 2007; Vazquez-Bustelo \& Avella, 2006b; Marin-Garcia \& Carneiro 2010). We extend previous researches in various aspects. First, we confirm that, in practice, the tools defined in production models alternative to mass production are basically the same, thus defining the set of tools important to use in a company. In the second place, a broad questionnaire representing a sufficient number of items and constructs related to the alternative tools to mass production is created. 
Moreover, we test the relationship between human key performance indicators (KPIs) and the operations tools in a sample other than the usual one (automotive, electronics, machinery).

People with disabilities are a social problem of increasing importance in Spanish society since, as it happens in many other countries, the unemployment rates of the disabled are much higher than the average. In this sense, one of the strategies most commonly adopted in many countries to facilitate the integration of disabled workers into the labor market has been the creation of sheltered work centers. This model of socio-labor integration tries to move away from the traditional stereotype that considers disabled people as unable to develop continuous professional work. Just as in any other firm, a sheltered work center competes in real markets and must be flexible and efficient enough to adapt to market fluctuations and changes, the only difference being that the sheltered work centers must have at least $70 \%$ of disabled workers. Moreover, the potential benefits that may be obtained from increased efficiency are usually invested into the growth of the sheltered work center, what results in more jobs for the disabled, which is in fact the primary aim of this kind of work centers. However, as the business environment is increasingly competitive, it is necessary to develop and implement the best practices for working with employees, equipment and materials in the Sheltered Work Centers.

To address the effect of lean production practices on the results, some authors use financial indicators (Molina, Llorens-Montes \& Ruiz-Moreno, 2007). However, most authors suggest analyzing the non-financial indicators, such as competitive advantage, because they reflect more clearly the direct impact of operations management practices and are less influenced by the crisis or deterioration of the variables socio-economic area outside the corporate action (Diaz, Gil \& Machuca, 2005; Fullerton \& McWatters, 2001).

The research presented in this paper reviews and summarizes the literature that investigates the relationship between individual practices of lean manufacturing with non-financial performance of the company, determines the extent to which Spanish Sheltered Work Centers have implemented lean manufacturing practices and the effect it produces in the non-financial performance of the company. We believe that our research is interesting because it describes the situation of a sector (Sheltered Work Centers) and one country (Spain) only investigated in the scientific literature on lean manufacturing. In addition, we will further analyze the effects that the implementation of lean manufacturing tools in companies of different sectors of the automobile. 


\section{Alternative tools for mass production}

Several authors consider that the expressions lean manufacturing, flexible, agile or mass customization represent different approaches to the productive system (Krishnamurthy \& Yauch, 2007; Da Silveira, Borenstein \& Fogliatto, 2001). Some opinions are based on the fact that a company using lean manufacturing can be considered to be a mass production company that has eliminated wastes whereas a flexible company is different because it has the capacity to better adjust to the environment but not so fast as an agile company (Duguay, Landry \& Pasin, 1997). On the other hand, the concept of agile manufacture is considered to be based on flexible manufacturing, lean manufacturing and Time based competition (VazquezBustelo \& Avella, 2006a). For this reason, the authors claim that agile manufacturing combines the efficiency of lean manufacturing with the operative flexibility of flexible manufacturing, offering personalized solutions with similar costs to mass production. After that, we provide a very brief review on each of these systems and verify whether they are really so different to each other with regards to the practices that they start up.

Lean manufacturing is dealt in the literature as a set of tools as its main objective eliminating the waste (time, space, personnel, material, rework, stocks, etc.) (Shah \& Ward, 2007). The list of lean manufacturing tools is large and not always homogenous, although they can be classified in five categories, namely total quality management (TQM), just-in-time (JIT), total preventive maintenance (TPM), supplier relationship, and product and process development (Swink, Narasimhan \& Kim, 2005; Bonavia \& Marin-Garcia, 2006; Gurumurthy \& Kodali, 2008; Carrasqueira \& Machado, 2008; Martinez Jurado \& Moyano Fuentes, 2011). Some authors include as a sixth element the continuous improvement culture and the worker involvement. But others consider that this element is necessary but independent of the specific practices of lean manufacturing (Ahmad, Schroeder \& Sinha, 2003; Sakakibara, Flynn, Schroeder \& Morris, 1997).

Flexible manufacturing is defined as the ability of a company to adapt to the demand fluctuations and the other changes in its environment (Duguay et al., 1997). But it is also understood as the capacity to produce diverse products under the same production chain, establishing an wide product range, admitting production volume modifications and multiple processes (Krishnamurthy \& Yauch, 2007). Flexible systems are focused, primordially, on production technology, including automated material handling systems and machinery (Krishnamurthy \& Yauch, 2007). The main objective of flexible manufacturing is to do the necessary 
changes to adapt to the new market requirements, to improve quality, costs, manufacturing times and delivery, simultaneously (Duguay et al., 1997). In order to ensure these objectives, it is necessary to maintain a closer relationship with customers and suppliers, use advanced manufacturing technologies, have an organizational structure with less levels and use innovative human resources policies (Duguay et al., 1997).

Most authors define agility as the ability to attend the customer's needs in the minor time possible and at low cost (Vazquez-Bustelo \& Avella, 2006a; Brown \& Bessant, 2003). It has been suggested that agile manufacturing groups up diverse techniques, among them just in time, cell manufacturing, flexible manufacturing and total quality management. All techniques are used with the objective to improve quality, productivity and customer service (Monplasir, 2002). Some authors claim that there exists a clear dividing line between lean manufacturing and agile manufacturing systems (Vazquez-Bustelo \& Avella, 2006a; Avella \& Vazquez-Bustelo, 2005). In principle, agile manufacture is an integration of both flexible manufacturing and lean manufacturing concepts (Vazquez-Bustelo \& Avella, 2006a).

Mass customization is a strategy related to the ability to offer customized products or services by means of flexible processes with high volumes and at a low cost (Krishnamurthy \& Yauch, 2007). The main objective of mass customization is to attend the customer specific necessities (Ahlstrom \& Westbrook, 1999). This is obtained by means of four customization profiles (Brown \& Bessant, 2003), which include designers who work together with their customers, products standard which the customer can change during use, a standard product set which is unique for each customer; and products which are modified according to specific individual needs. Mass customization uses some elements of lean manufacturing (product development, supplier chain management, production management, continuous improvement), which includes the after-sales service and marketing (Da Silveira et al., 2001).

Reviewing the information commented in the previous paragraphs, it seems possible that the principles or underlying philosophies of each of the systems are different. Nevertheless, if we pay attention only to the practices that are put into practice (table 1 ), we can see that they are mainly very similar. As table 1 shows, the set of alternative practices to mass production can be classified in around 6 constructs and 16 dimensions with good references in the academic literature. 


\begin{tabular}{|c|c|c|}
\hline Construct & Dimensions & Lean manufacturing \\
\hline \multirow{3}{*}{$\begin{array}{l}\text { Total Quality } \\
\text { Management }\end{array}$} & Visual Management & \multirow{3}{*}{$\begin{array}{l}\text { Doolen \& Hacker, 2005; Shah \& Ward, 2007; } \\
\text { Marin-Garcia, Pardo del Val, \& Bonavia, } \\
\text { 2006; Gurumurthy \& Kodali, } 2008\end{array}$} \\
\hline & Continuous I mprovement & \\
\hline & Process control & \\
\hline \multirow{5}{*}{ One piece flow } & JIT/ Kanban & \multirow{5}{*}{$\begin{array}{l}\text { Shah \& Ward, 2007; Kannan \& Tan, 2005; } \\
\text { Doolen \& Hacker, 2005; Gurumurthy \& } \\
\text { Kodali, 2008; Marin-Garcia et al., 2006; } \\
\text { Treville \& Antonakis, 2006; Carrasqueira \& } \\
\text { Machado, } 2008\end{array}$} \\
\hline & Process Standardization & \\
\hline & $\begin{array}{l}\text { Single-minute Exchange of die } \\
\text { (SMED) }\end{array}$ & \\
\hline & Line Balancing & \\
\hline & $\begin{array}{l}\text { Continuous flow and Cell } \\
\text { manufacturing }\end{array}$ & \\
\hline Maintenance & Maintenance & $\begin{array}{l}\text { Shah \& Ward, 2007; Doolen \& Hacker, 2005; } \\
\text { Gurumurthy \& Kodali, 2008; Marin-Garcia et } \\
\text { al., } 2006\end{array}$ \\
\hline $\begin{array}{l}\text { Supplier } \\
\text { relationship }\end{array}$ & Supplier relationship & $\begin{array}{l}\text { Shah \& Ward, 2007; Doolen \& Hacker, 2005; } \\
\text { Kannan \& Tan, 2005; Gurumurthy \& Kodali, } \\
\text { 2008; Carrasqueira \& Machado, 2008; Alfalla } \\
\text { Luque \& Medina López, 2009; Martinez } \\
\text { Jurado \& Moyano Fuentes, } 2011\end{array}$ \\
\hline $\begin{array}{l}\text { Customer } \\
\text { relationship }\end{array}$ & Customer relationship & $\begin{array}{l}\text { Shah \& Ward, 2007; Doolen \& Hacker, 2005; } \\
\text { Gurumurthy \& Kodali, 2008; Carrasqueira \& } \\
\text { Machado, 2008; Alfalla Luque \& Medina } \\
\text { López, 2009 }\end{array}$ \\
\hline \multirow{5}{*}{$\begin{array}{l}\text { Human Resources } \\
\text { Management }\end{array}$} & Empowerment & \multirow{5}{*}{$\begin{array}{l}\text { Perello-Marin, 2010; Marin-Garcia \& Conci, } \\
\text { 2009; Gibson, Porath, Benson, \& Lawler III, } \\
\text { 2007; Marin-Garcia \& Bonavia, 2011; } \\
\text { Bonavia \& Marin-Garcia, 2011; Guerrero \& } \\
\text { Barraud-Didier, 2004; Katou, } 2008\end{array}$} \\
\hline & Training & \\
\hline & Team-work & \\
\hline & Rewards & \\
\hline & Communication & \\
\hline
\end{tabular}

Table 1. Constructs and dimensions of alternative tools to mass manufacturing included in previous research

Most articles published on the effect of lean production on non-financial performance of the company, have taken joint lean manufacturing practices (constructs) and analyzed their relationship on performance indicators independently (Cua, McKone \& Schroeder, 2001; Flynn \& Sakakibara, 1995; Ketokivi \& Schroeder, 2004; McKone, Schroeder \& Cua, 2001). However, there is very little research on the effects of alternative practices to mass production on human performance indicators.

\section{Methodology}

The population subject to this study is composed by Sheltered Work Centers for disabled in Spain (646). After a first telephone contact with the company, an electronic mail address from a person with a responsible job in that same company (Manager, Person in charge of Production, Person in charge of Quality) was requested so that we could send the link to the questionnaire which was to be completed on the Web site. If a questionnaire was not completed, up to three electronic mails were sent before the questionnaire was considered to be unanswered. A total of 237 answers were received. Only 128 of them had all the 
complete data (19.81\% rate of answer), which was the information used in the research. We use Regression analysis in order to probe relations between explicative and criterion variables.

\section{Results and discussion}

Table 2 summarises the descriptive statistics of the items forming the factors included in the research. The degree of use of alternative practices to mass production vastly varies amongst the companies included in the survey. Thus, while practices such as customer relationship or human resources management are quite frequent, practices as the use of one piece flow or maintenance are almost non-existent. In general, the factors of customer relationship, continuous improvement, standardization of processes, cell manufacturing and supplier relationship are the most widely implemented in the surveyed companies. In the opposite end, practices like JIT/Kanban and SMED virtually do not appear to be deployed. The rest of the factors are shown as being moderately introduced. Human resource KPIs (competitive advantage against ordinary firms) are rated medium to high, but the percentage of workers who become integrated into ordinary companies is extremely low.

\begin{tabular}{|l|r|r|r|r|r|}
\hline & \multicolumn{1}{l|}{ M } & \multicolumn{1}{l|}{ Min } & \multicolumn{1}{l|}{ Max } & \multicolumn{1}{l|}{ Mean } & \multicolumn{1}{l|}{ Std. Dev. } \\
\hline Customer relationship & 128 & 0 & 5,00 & 3,0684 & 1,29143 \\
\hline Supplier relationship & 128 & 0 & 5,00 & 2,3117 & 1,04419 \\
\hline One piece flow & 128 & 0 & 5,00 & 1,6800 & 1,05850 \\
\hline Total Quality Management & 128 & 0 & 4,82 & 2,4467 & 1,01247 \\
\hline Human Resources Management & 128 & 0 & 4,58 & 2,7697 & 0,87118 \\
\hline Maintenance & 128 & 0 & 5,00 & 2,1354 & 1,54557 \\
\hline Job satisfaction & 113 & 3 & 5 & 3,62 & 0,623 \\
\hline Permanent contracts & 112 & 2 & 5 & 3,91 & 0,787 \\
\hline Knowledge & 112 & 1 & 5 & 3,15 & 0,782 \\
\hline Workers who become integrated into ordinary companies & 37 & 1 & 4 & 1,86 & 0,910 \\
\hline Personal\& social adjustment activities & 38 & 1 & 5 & 3,63 & 1,057 \\
\hline Less absenteeism & 83 & 1,00 & 5,00 & 3,1566 &, 89008 \\
\hline Less Voluntary turnover & 83 & 2,00 & 5,00 & 3,9036 &, 80569 \\
\hline
\end{tabular}

Table 2. Descriptive Statistics of variables

Analyzing the results of multivariate regressions (table 3 ); we see that the main effects are generated by close relationships with customers and management of human resources. The first one generates demand stability and continuity of sheltered work centers. Because this more satisfaction, a more stable contracts, the ability to perform more activities of personal and social adjustment, and less intentions to withdraw from the company is achieved. The second is a tool that clearly affects the job satisfaction and training of employees. However, the explanatory power of the variables used is quite low (between $4 \%$ and $27 \%$ ). 
These figures, although still common in research in the area, suggest us that human KPIs are mainly affected by a different variance sources than operations management tools. At least this is the conclusion we can draw for companies in this industry that participated in the sample.

Moreover, it is noteworthy that none of the variables has been able to significantly affect the integration of disabled staff in ordinary companies. It is also awaiting further analysis that the use of preventative or autonomous maintenance is related to less absenteeism in companies.

\begin{tabular}{|c|c|c|c|c|c|c|c|}
\hline Human KPI $\rightarrow$ & $\begin{array}{l}\text { Job } \\
\text { satisfaction }\end{array}$ & $\begin{array}{l}\text { Permanent } \\
\text { contracts }\end{array}$ & Knowledge & $\begin{array}{l}\text { integration } \\
\text { into } \\
\text { ordinary } \\
\text { companies }\end{array}$ & $\begin{array}{l}\text { Personal\& } \\
\text { social } \\
\text { adjustment }\end{array}$ & $\begin{array}{l}\text { Less } \\
\text { absenteeism }\end{array}$ & $\begin{array}{l}\text { Less } \\
\text { Voluntary } \\
\text { turnover }\end{array}$ \\
\hline $\begin{array}{l}\text { Customer } \\
\text { relationship }\end{array}$ & $1,812+$ & $0,249 * *$ & 0,068 & 0,031 & $0,408 * *$ & 0,019 & $0,219+$ \\
\hline $\begin{array}{l}\text { Supplier } \\
\text { relationship }\end{array}$ & 0,266 & $-0,247 * *$ & $-0,126$ & $-0,142$ & $-0,151$ & $-0,066$ & $-0,147$ \\
\hline $\begin{array}{l}\text { One piece } \\
\text { flow }\end{array}$ & $-1,212$ & 0,056 & 0,031 & $-0,252$ & $-0,026$ & $-0,107$ & 0,0212 \\
\hline $\begin{array}{l}\text { Total Quality } \\
\text { Management }\end{array}$ & $-0,807$ & $-0,240$ & $-0,064$ & 0,086 & 0,246 & $-0,029$ & $-0,226$ \\
\hline $\begin{array}{l}\text { Human } \\
\text { Resources } \\
\text { Management }\end{array}$ & $2,494 * *$ & 0,178 & $0,298 * *$ & 0,316 & 0,063 & $-0,032$ & 0,008 \\
\hline Maintenance & $-0,371$ &, 050 & 0,082 & $-0,011$ & 0,051 & $0,271+$ & 0,064 \\
\hline $\mathrm{R} 2$ & 0,099 & 0,090 & 0.094 & 0,163 & 0,273 & 0,042 & 0,082 \\
\hline
\end{tabular}

Table 3. Relationship between human KPIs and alternative tools to mass production (regression standardized Beta)

\section{Conclusions}

Lean manufacturing practices can be divided into six constructs with several dimensions each. There are few papers relating lean manufacturing tools and human resources performance indicators. At the same time, there are very few research carried out in Sheltered Work Centers context. The results of our research allow us to identify four constructs with significant effects on the human KPIs (job satisfaction, knowledge, integration into ordinary companies and personal and social adjustment). It would be desirable to extend this research to analyze in detail the particular effect of each of the sixteen dimensions on the human KPIs.

Our research has some limitations: data came from a single informant, and all the companies are Sheltered Work Centers; therefore the results would not be directly generalized to other contexts.

We believe that Sheltered Work Centers managers can use the results of our research to estimate the effect that certain tools have on human resources. On the 
one hand, we present a set of indicators of interest to businesses. Furthermore, we show which practices seem to have more impact on each of the indicators. On the other hand, we also present an estimate of the degree of deployment of alternative practices to mass production in Sheltered Work Centers. In this way, companies can compare their deployment with the industry average.

\section{Acknowledgments}

This research was supported by the project "Arquitectura de las prácticas de alto rendimiento de gestión de operaciones y gestión de recursos humanos: definición de los constructos, modelo factorial y establecimiento del path dependence" (PAID06-09-2850) from Universidad Politécnica de Valencia. This support is gratefully acknowledged.

\section{References}

Agarwal, A., Shankar, R., \& Tiwari, M.K. (2006). Modeling the metrics of lean, agile and leagile supply chain: An ANP-based approach. European Journal of Operational Research, 173(1), 211-225. http://dx.doi.org/10.1016/i.ejor.2004.12.005

Ahlstrom, P. \& Westbrook, R. (1999). Implications of mass customization for operations management: An exploratory survey. International Journal of Operations \& Production Management, 19(3), 262-274. http://dx.doi.org/10.1108/01443579910249705

Ahmad, S., Schroeder, R.G., \& Sinha, K.K. (2003). The role of infrastructure practices in the effectiveness of JIT practices: implications for plant competitiveness. Journal of Engineering and Technology Management, 20(3), 161-191. http://dx.doi.org/10.1016/S0923-4748(03)00017-1

Alfalla Luque, R. \& Medina López, C. (2009). Supply Chain Management: unheard of in the 1970s, core to today's company. Business History, 51(2), 202-221.

Avella, L. \& Vazquez-Bustelo, D. (2005). ¿Es la fabricación ágil un nuevo modelo de producción? Universia Business Review - Actualidad Económica, 6, 94-107.

Bonavia, T. \& Marin-Garcia, J.A. (2006). An empirical study of lean production in ceramic tile industries in Spain. International Journal of Operations \& Production Management, 26(5), 505-531. http://dx.doi.org/10.1108/01443570610659883 
Bonavia, T. \& Marin-Garcia, J.A. (2011). Integrating human resource management into lean production and their impact on organizational performance. International Journal of Manpower, In press.

Brown, S. \& Bessant, J. (2003). The manufacturing strategy-capabilities links in mass customisation and agile manufacturing--an exploratory study. International Journal of Operations \& Production Management, 23(7), 707. http://dx.doi.org/10.1108/01443570310481522

Carrasqueira, M. \& Machado, V.C. (2008). Strategic logistics: Re-designing companies in accordance with Lean Principles. International Journal of Management Science and Engineering Management, 3(4), 294-302.

Cua, K., McKone, K., \& Schroeder, R.G. (2001). Relationships between implementation of TQM, JIT, and TPM and manufacturing performance. Journal of Operations Management, 19(6), 675-694. http://dx.doi.org/10.1016/S02726963(01)00066-3

Da Silveira, G., Borenstein, D., \& Fogliatto, F.S. (2001). Mass customization: Literature review and research directions. International Journal of Production Economics, 72 1-13. http://dx.doi.org/10.1016/50925-5273(00)00079-7

Diaz, M.S., Gil, M.J.A., \& Machuca, J.A.D. (2005). Performance measurement systems, competitive priorities, and advanced manufacturing technology - Some evidence from the aeronautical sector. International Journal of Operations \& Production Management, 25(7-8), 781-799. http://dx.doi.org/10.1108/01443570510608600

Doolen, T.L. \& Hacker, M.E. (2005). A Review of Lean Assessment in Organizations: An Exploratory Study of Lean Practices by Electronics Manufacturers. International Journal of Manufacturing Systems, 24(1), 55-67. http://dx.doi.org/10.1016/50278$\underline{6125(05) 80007-X}$

Duguay, C., Landry, S., \& Pasin, F. (1997). From mass production to flexible/agile production. International J ournal of Operations\& Production Management, 17(12), 1183-1195. http://dx.doi.org/10.1108/01443579710182936

Flynn, B. B. \& Sakakibara, S. (1995). Relationship between JIT and TQM: Practices and performance. Academy of management Journal, 38(5), 1325. http://dx.doi.org/10.2307/256860 
Fullerton, R.R. \& McWatters, C.S. (2001). The production performance benefits from JIT implementation. Journal of Operations Management, 19(1), 81-96. http://dx.doi.org/10.1016/S0272-6963(00)00051-6

Gibson, C.B., Porath, C.L., Benson, G.S., \& Lawler III, E.E. (2007). What results when firms implement practices: The differential relationship between specific practices, firm financial performance, customer service, and quality. Journal of Applied Psychology, 92(6), 1467-1480. http://dx.doi.org/10.1037/0021-9010.92.6.1467

Guerrero, S. \& Barraud-Didier, V. (2004). High-involvement practices and performance of French firms. International Journal of Human Resource Management, 15(8), 1408-1423. http://dx.doi.org/10.1080/0958519042000258002

Gurumurthy, A. \& Kodali, R. (2008). A multi-criteria decision-making model for the justification of lean manufacturing systems. International Journal of Management Scienceand Engineering Management, 3(4), 100-118.

Holweg, M. (2007). The genealogy of lean production. Journal of Operations Management, 25(2), 420-437. http://dx.doi.org/10.1016/i.jom.2006.04.001

Ismail, H., Reid, I., Mooney, J., Poolton, J., \& Arokiam, I. (2007). How small and medium enterprises effectively participate in the mass customization game. IEEE Transactions on Engineering Management, 54(1), 86-97. http://dx.doi.org/10.1109/TEM.2006.889069

Kannan, V.R. \& Tan, K.C. (2005). Just in time, total quality management, and supply chain management: understanding their linkages and impact on business performance. Omega-International Journal of Management Science, 33(2), 153162. http://dx.doi.org/10.1016/i.omega.2004.03.012

Katou, A.A. (2008). Measuring the impact of HRM on organizational performance. Journal of Industrial Engineering and Management, 1(2), 119-142. http://dx.doi.org/10.3926/jiem.2008.v1n2.p119-142

Ketokivi, M. \& Schroeder, R.G. (2004). Manufacturing practices, strategic fit and performance: A routine-based view. International Journal of Operations \& Production Management, 24(1/2), 171. http://dx.doi.org/10.1108/01443570410514876

Krishnamurthy, R. \& Yauch, C.A. (2007). Leagile manufacturing: A proposed corporate. International J ournal of Operations \& Production Management, 27(6), 588-604. http://dx.doi.org/10.1108/01443570710750277 
Marin-Garcia, J.A. \& Bonavia, T. (2011). Strategic Priorities and Lean Manufacturing Practices in Automotive Suppliers. Ten Years After. In M.Chiaberge (Ed.), New Trends and Developments in Automotive Engineering. InTech.

Marin-Garcia, J.A. \& Carneiro, P. (2010). Desarrollo y validación de un modelo multidimensional de la producción ajustada. Intangible Capital, 6(1), 78-127.

Marin-Garcia, J.A. \& Conci, G. (2009). Exploratory study of high involvement work practices: Identification of the dimensions and proposal of questionnaire to measure the degree of use in the company. Intangible Capital, 5(3), 278-300. http://dx.doi.org/10.3926/ic.2009.v5n3.p278-300

Marin-Garcia, J.A., Pardo del Val, M., \& Bonavia, T. (2006). The Impact of Training and ad hoc Teams in Industrial Settings. International Journal of Management Science and Engineering Management, 1(2), 137-147.

Martín Peña, M.L. \& Díaz Garrido, E. (2007). Impacto de la estrategia de producción en la ventaja competitiva y en los resultados operativos. International Conference on Industrial Engineering \& Industrial Management - CIO, 367-377. Madrid.

Martinez Jurado, P.J . \& Moyano Fuentes, J. (2011). Lean Production y gestión de la cadena de suministro en la industria aeronáutica. Investigaciones Europeas de Dirección y Economía de la Empresa, 17(1), 137-157.

McKone, K.E., Schroeder, R.G., \& Cua, K.O. (2001). The impact of total productive maintenance practices on manufacturing performance. Journal of Operations Management, 19(1), 39-58. http://dx.doi.org/10.1016/S0272-6963(00)00030-9

Molina, L.M., Llorens-Montes, J., \& Ruiz-Moreno, A. (2007). Relationship between quality management practices and knowledge transfer. Journal of Operations Management, 25(3), 682-701. http://dx.doi.org/10.1016/j.jom.2006.04.007

Monplasir, L. (2002). Enhancing CSCW with Advanced Decision Making Tools for an Agile Manufacturing System Design Application. Group Decision and Negotiation, 11, 45-63. http://dx.doi.org/10.1023/A:1014538003326

Narain, R., Yadav, R.C., \& Antony, J. (2004). Productivity gains from flexible manufacturing: Experiences from India. International Journal of Productivity and Performance Management, $53(2)$, 109-128. http://dx.doi.org/10.1108/17410400410515025 
Perello-Marin, M.R. (2010). Towards a methodology for identifying path dependence in the evolution of human resources practices. Working Papers on Operations Management, 1(1), 56-58.

Portioli Staudacher, A. \& Tantardini, M. (2007). Lean Production implementation: A survey in Italy. International Conference on Industrial Engineering \& Industrial Management - ClO, 1269-1279. Madrid.

Sakakibara, S., Flynn, B.B., Schroeder, R.C., \& Morris, W.T. (1997). The impact of Just-In-Time manufacturing and its infrastructure on manufacturing performance. Management Science, 43(9), 1246. http://dx.doi.org/10.1287/mnsc.43.9.1246

Shah, R. \& Ward, P.T. (2007). Defining and developing measures of lean production. Journal of Operations Management, 25(4), 785-805. http://dx.doi.org/10.1016/i.jom.2007.01.019

Swink, M., Narasimhan, R., \& Kim, S.W. (2005). Manufacturing practices and strategy integration: Effects on cost efficiency, flexibility, and market-based performance. Decision Sciences, 36(3), 427-457. http://dx.doi.org/10.1111/i.15405414.2005.00079.x

Tari, J.J., Molina, J.F., \& Castejón, J.L. (2007). The relationship between quality management practices and their effects on quality outcomes. European Journal of Operational Research, 183(2), 483-501. http://dx.doi.org/10.1016/j.ejor.2006.10.016

Treville, S.D. \& Antonakis, J. (2006). Could lean production job design be intrinsically motivating? Contextual, configurational, and levels-of-analysis issues. Journal of Operations Management, 24(2), 99-123. http://dx.doi.org/10.1016/j.jom.2005.04.001

Urgal González, B., Diz Comesaña, M.E., \& García Vázquez, J.M. (2007). Automatización flexible, Ingeniería de diseño y fabricación, gestión de la calidad y empowerment: Evidencia empírica de su contribución a la creación de capacdidades estratégicas. Dirección y Organización, 33, 35-52.

Vazquez-Bustelo, D., \& Avella, L. (2006a). Agile manufacturing: Industrial case studies in Spain. Technovation, 26, 1147-1161. http://dx.doi.org/10.1016/j.technovation.2005.11.006

Vazquez-Bustelo, D., \& Avella, L. (2006b). Contraste empírico del modelo de fabricación ágil en España. XVI congreso nacional de la Asociación Científica de Economía y Dirección de Empresas Valencia. 
Journal of Industrial Engineering and Management, 2011 (www.jiem.org)

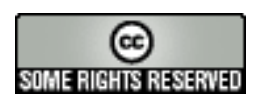

Article's contents are provided on a Attribution-Non Commercial 3.0 Creative commons license. Readers are allowed to copy, distribute and communicate article's contents, provided the author's and Journal of Industrial Engineering and Management's names are included. It must not be used for commercial purposes. To see the complete license contents, please visit http://creativecommons.org/licenses/by-nc/3.0/. 